\title{
PENGARUH SISTEM MANAJEMEN KEPALA SEKOLAH \\ DAN KINERJA GURU TERHADAP KUALITAS PEMBELAJARAN \\ DI SEKOLAH DASAR LABORATARIUM PPL UPI \\ KECAMATAN CILEUNYI KABUPATEN BANDUNG
}

\section{Ening Widaningsih}

\begin{abstract}
Abstrak
istem manajemen kepala sekolah dengan memfungsikan fungsi manajemen yang meliputi:

$S$ perencanaan (planning), pengorganisasian (organization), penggerakkan (actuating), pengkoordinasian (coordinating), pengarahan (directing), pengawasan (controlling), dapat mengefektifkan dan mengefisienkan sumber daya yang ada di sekolahnya diantaranya kinerja mengajar guru demikian juga kinerja guru mempengaruhi terhadap kualitas
\end{abstract} pembelajaran.

Tujuan penelitian untuk mengetahui gambaran empiris tentang: (1) pelaksanaan system manajemen kepala sekolah; (2) kinerja mengajar guru; (3) kualitas pembelajaran; (4) pengaruh system manajemen terhadap kinerja mengajar guru; (5) pengaruh kinerja mengajar guru terhadap kualitas pembelajaran; (6) pengaruh system manajemen kepala sekolah terhadap kualitas pembelajaran; (7) pengeruh system manajemen kepala sekolah dan kinerja mengajar guru secara simultan terhadap kualitas pembelajaran.

Hasil penelitian ini menunjukkan bahwa (1) pelaksanaan system manajemen kepala sekolah menghasilkan angka rata rata 4,04 artinya system manajemen kepala sekolah di SD Laboratorium PPL UPI secara umum tergolong baik; (2) kinerja mengajar guru menghasilkan angka rata rata 4,09 artinya kinerja pengajar guru di SD Laboratorium PPLUPI secara umum tergolong baik; (3) kualitas pembelajaran dipresentasikan dalam nilai rata rata yang diperoleh seluruh siswa kelas I sampai dengan kelas VI pada sekolah yang bersangkutan adalah 6,97 pada skala 10, angka tersebut mendekati 7 sehingga dapat ditafsirkan bahwa kualitas pembelajaran pada SD Laboratorium PPL UPI termasuk katogori lebih dari cukup; (4) ada pengaruh positif signifikan system manajemen terhadap kinerja guru sebesar 15,70\%; (5) terhadap kualitas pembelajaran sebesar 10,90 \%; (6) kinerja mengajar guru berpengaruh terhadap kualitas pembelajaran sebesar 25,00\%; dan (7) sistem manajemen kepala sekolah dan kinerja mengajar guru berpengaruh positif terhadap pembelajaran sebesar $27,00 \%$.

Kata Kunci: manajemen kepala sekolah; kinerja guru; kualitas pembelajaran
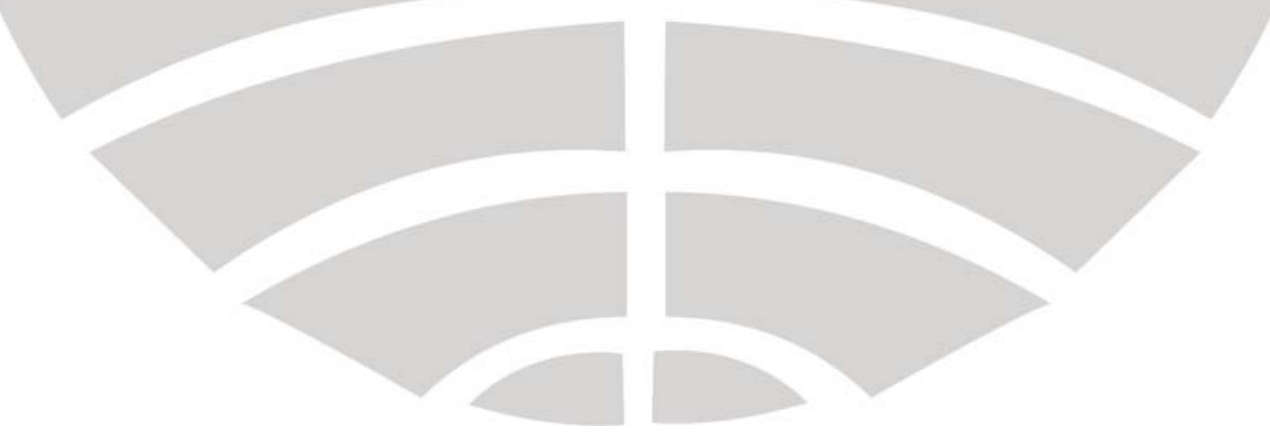


\section{LATAR BELAKANG MASALAH}

Melihat dokumen sekolah mengenai kelembagaan, ketenagaan, perlengkapan dan sebagainya akan nampak jelas mana yang termasuk unsure intern organisasi dan mana yang termasuk ekster tersebut, sekolah sebagai suatu organisasi bersifat kompleks dan unik dengan sifat yang kompleks dan unik tersebut sekolah memerlukan tingkat koordinasi yang tinggi, koordinasi sekolah tidak lain adalah tanggung jawab dari pimpinan yaitu kepala sekolah. Selanjutnya dapat dikatakan bahwa keberhasilan kepala sekolah adalah keberhasilan sekolah atau sebaliknya. Pengertian kepala sekolah dapat dilihat dari kata pembentuknya, yaitu" kepala" dan "sekolah" dapat diartikan sebagai "ketua" atau "pimpinan" suatu organisasi. Sedangkan "sekolah" dapat diartikan sebagai organisasi atau lembaga dimana dilaksanakan proses pembelajaran.

Sebagaimana dikemukakan oleh Wahyosumidjo, (1999) "Kepala sekolah dapat didefinisikan sebagai"seorang tenaga professional guru" yang diberi tugas untuk memimpin suatu sekolah dimana diselenggarakannya proses belajar mengajar atau dimana terjadinya interaksi antara guru yang memberi pelajaran". Kepala sekolah berupaya mencurahkan kemampuannya dalam mencapai tujuan, hal ini menunjukkan bahwa kepemimpinan merupakan sumbangan dari seseorang dalam mencapai tujuan " Kepemimpinan berarti kemampuan dan kesiapan yang dimiliki oleh seseorang untuk mempengaruhi, mendorong, mengajak, menuntun, menggerakkan, dan mengarahkan dan selanjutnya berbuat sesuatu yang dapat membantu tercapainya tujuan tertentu yang telah dikemukakan". (Team Dosen Jurusan Administrasi Pendidikan, 2003).

Kepala sekolah dalam upaya mencapai tujuan pendidikan ditentukan pula oleh peran administrasi dalam penyelenggarakan pendidikan itu sendiri. Desain organisasi sekolah adalah di dalamnya terdapat tim administrasi sekolah yang terdiri dari sekelompok orang yang bekerja sama dalam rangka mencapai tujuan organisasi. Tujuan utama tim administrasi sekolah adalah untuk mengembangkan prosedur kebijakan sekolah, memecahkan masalah umum pendidikan, memangfaatkan semua potensi individu yang tergabung dalam tim tersebut.

Untuk mewujudkan harapan seperti di atas, diperlukan peran/ pengaruh dari kepemimpinan kepala sekolah yang dapat memperdayakan potensi para personil sekolah, dalam hal ini guru diantaranya yang dapat juga berpengaruh terhadap keberhasilan pendidikan tersebut.

Pandangan ini diperkuat pernyataan yang dikeluarkan Depdikbud (1994:63), bahwa "Guru adalah sumber daya manusia yang diharapkan mampu, mengarahkan dan mendayagunakan factor factor yang lainnya sehingga tercipta proses belajar mengajar yang berkualitas. Tanpa mengabaikan factor factor lain, guru dapat dianggap sebagai factor utama yang menentukan terhadap meningkatnya mutu pendidikan".

Dari pandangan di atas jelas menunjukkan bahwa guru sebagai tenaga operasional pendidikan merupakan suatu komponen atau factor utama, tanpa guru tujuan pendidikan tidak akan tercapai. Produktifitas sekolah baik kualitas maupun kuantitas sangat ditentukan oleh penampilan mengajar guru (teaching performance) Guru sebagai pelaku pendidikan yang secara makro mengemban tugas sebagai seorang pendidik, merupakan factor yang sangat menentukan tinggi rendahnya kualitas pendidikan. Kondisi tersebut menuntut sosok pribadi guru yang berkualitas memadai atau sesuai dengan tuntutan kebutuhan masyarakat. Berbagai studi menunjukkan bahwa guru dapat mempengaruhi perilaku belajar anak/ siswa lebih efektif. Fungsi guru yang langsung menangani proses pembelajaran dikelas sangat strategis dalam upaya meningkatkan manajemen sekolah terutama dalam kaitannya dengan proses pembelajaran tersebut. Guru dalam kaitannya dengan interaksi pembelajaran menunjukkan kinerjanya, 
hal ini sejalan dengan pendapat Rochman Natawijaya (1999), " Kinerja guru dapat dilihat saat melaksanakan interaksi belajar mengajar di kelas termasuk bagaimana dia mempersiapkannya"

\section{RUMUSAN MASALAH}

Masalah dalam penelitian ini dapat dirumuskan sebagai berikut.

1. Bagaimana kualitas pembelajaran di SD Laboratorium PPL UPI Kecamatan Cileunyi?

2. Bagaimana system manajemen Kepala Sekolah di SD PLL UPI Kecamatan Cileunyi?

3. Bagaimana kinerja guru di SD Laboratorium PPL UPI Kecamatan Cileunyi

4. Apakah ada pengaruh system manajemen dan kinerja guru terhadap kualitas pembelajaran di SD Laboratorium PPL UPI Kecamatan Cileunyi?

\section{TUJUAN PENELITIAN}

Tujuan penelitian ini adalah untuk mengetahui gambaran empiris tentang: (1) pelaksanaan system manajemen kepala sekolah; (2) kinerja mengajar guru; (3) kualitas pembelajaran; (4) pengaruh system manajemen terhadap kinerja mengajar guru; (5) pengaruh kinerja mengajar guru terhadap kualitas pembelajaran; (6) pengaruh system manajemen kepala sekolah terhadap kualitas pembelajaran; (7) pengeruh system manajemen kepala sekolah dan kinerja mengajar guru secara simultan terhadap kualitas pembelajaran.

\section{TINJAUAN PUSTAKA}

Wahyosumidjo (1999) "kepala sekolah adalah jabatan pemimpin yang tidak bisa diisi orang lain tanpa didasarkan atas pertimbangan.Siapapun yang diangkat menjadi kepala sekolah harus ditentukan melalui prosedur serta persyaratan persyaratan seperti latar belakang pendidikan, pengalaman, usia, pangkat dan integritas" Kepala sekolah merupakan tenaga professional yang berwenang untuk memajukan dan mengembangkan sekolah, hal ini menurut Ki Suprayoko ( 1997), menegaskan "peran kepala sekolah sebagai pemikir dan pengembang". Kepala sekolah tenaga professional yang mempunyai wewenang untuk memajukan dan mengembangkan sekolah diharapkan mampu menghadapi competitor, dituntut memiliki kompetensi untuk menunjang dalam tugas tugas yang dihadapinya.

Dalam Pola Pembaharuan Sistem Pendidikan Tenaga Kependidikan di Indonesia dikemukakan tiga dimensi umum kompetensi professional tenaga kependidikan yaitu kompetensi pribadi, kompetensi profesi dan kompetensi kemasyarakatan atau social. Kepala sekolah sebagai pengambil keputusan tertinggi di sekolah dan setiap keputusan/ tindakan yang diambil semata mata untuk peningkatan efisiensi yang didasarkan pada permasalahan yang sedang dihadapi oleh sekolah yang bersangkutan; Sebagai penanggung jawab dalam penyelenggaraan proses pembelajaran, kepala sekolah memahami penempatan guru sesuai dengan bidangnya masing masing, mengupayakan ketersediaan sarana prasarana, mengawsi pelaksanaannya dan mempersiapkan program evaluasi sel;anjutnya ditindaklanjuti dengan laporan kepada orang tua siswa maupun kepada instansi yang terkait. Hal in semua sesuai dengan yang dikemukakan Jack Mc. Crudy (1983: 41) bahwa: "sebagai pemimpin pengajaran kepala sekolah wajib mengabdikan dirinya pada enam bidang yaitu: (1) orang, (2) bantuan alat pengajaran, (3) 
sumber yang memadai, (4) kualitas pengawasan (quality control), (5) koordinasi kegiatan sekolah, dan (6) pemecahan masalah.

Untuk mempertahankan kekuasaan sekaligus untuk mengsukseskan tugasnya, menurut Pidarta, kepala sekolah perlu memiliki ketrampilan sebagai berikut: Ketrampilan proses, artinya ketrampilan untuk menciptakan konsep baru baik untuk kepentingan manajemen maupun administrasi sekolah, ketrampilan manusiawi, yaitu kemampuan administrator, berkomunikasi bergaul, membina,dan memajukan perilaku para personalia sekolah terutama guru guru di sekolah, ketrampilan teknik, artinya keterampilan tentang teknik teknik mendidik, mengajar dan ketatausahaan.

Peranan kepala sekolah dalam konteks manajemen sekolah menurut Turney et all (1992) the planning role, the communicating role, the organizing role, the motivating role, dan the controlling role.

Tinjauan administrasi sekolah dasar menurut Winarno Surachman (1982 :6) Administrasi sekolah dasar adalah keseluruhan kegiatan kerja sama antara orang orang yang berada di sekolah dasar untuk mencapai tujuan penyelenggaraan sekolah dasar". Basari Mukti (1992/1993: 21), menegaskan kegiatan administrasi sekolah dasar meliputi: kurikulum, kemuridan, keuangan, sarana dan prasarana, kepegawaian, layanan khusus, hubungan sekolah dan masyarakat.

System manajemen kepala sekolah dalam rangka menyelenggarakan program pendidikan termasuk jenjang sekolah dasar untuk mencapai tujuan pendidikan yang telah ditentukan, secara operasional memfungsikan fungsi manajemen dimulai dengan hal-hal sebagai berikut pertama, Perencanaan (planning). Kedua, Pengorganisasian (organizing), diartikan sebagai kegiatan membagi tugas-tugas pada orang yang terlibat kerja sama pendidikan. Ketiga, Penggerakan (actuating), merupakan usaha untuk menggerakkan personil lembaga sedemikian rupa sehingga setiap personil berkeinginan dan berusaha mencapai tujuan yang telah direncanakan bersama. Keempat, Pengkoordinasian (coordinating), mengandung makna agar tugas-tugas dibagikan dapat dikerjakan dengan tepat, lebih-lebih dalam lembaga pendidikan dimana ada tugas substansi yaitu pekerjaan mendidik, termasuk memenej satuan pendidikan dan memenej pembelajaran. Kelima, pengarahan (directing), dalam kegiatan pendidikan masing-masing personil memerlukan arahan dari kepala sekolah agar tidak saja mengetahui apa tugas dan menjadi tanggung jawabnya tetapi juga memahami harapanharapan kepala sekolah itu sendiri disamping dapat memungkinkan mengembangkan kemampuankemampuan guru atau personil lainnya. Keenam, pengawasan (controlling), adalah proses monitor aktivitas-aktivitas untuk mengetahui apakah individu-individu dan organisasi itu sendiri memperoleh dan memanfaatkan sumber-sumber secara efektif dan efisien dalam mencapai tujuan.

Keseluruhan dari kegiatan memfungsikan fungsi manajemen dari seorang kepala sekolah dalam menyelenggarakan program pendidikan di sekolah binaannya masing-masing, harus mampu mempengaruhi kinerja guru. Mengingat dalam penyelenggaraan program khususnya dalam pembelajaran guru merupakan factor penting dan dominan. Guru melalui kinerjanya dapat menentukan kwalitas pembelajaran " A good teaching depend on a good teacher ". (Dahana dan Bkatnager, 1980). Kinerja guru memiliki kemampuan professional tidak saja dapat menguasai materi pembelajaran dituntut pula memiliki kemampuan manejerial dalam proses belajar mengajar, guru harus mampu berperan sebagai " A manager of children's learning ". (Dean,1983).

Pembelajaran inti proses pendidikan secara keseluruhan, pembelajaran secara aktualisasi kurikulum yang menuntut keaktifan guru dalam menciptakan dan menumbuhkan kegiatan peserta didik sesuai dengan rencana yang telah diprogramkan dan melalui proses pembelajaran memungkinkan siswa mengalami perubahan baik dalam pengetahuan (kognitif), ketrampilan (psiomotor), maupun perubahan dalam sikap (afektif). Atas keberhasilan-keberhasilan tersebut sekaligus dapat dikatan tercapainya kualitas pembelajaran yang baik, hal ini seperti pendapat yang dikemukakan oleh E.Mulyasa, bahwa

Kualitas pembelajaran atau pembentukan kompetensi dalam dapat dilihat dari segi hasil. Dari segi proses, pembelajaran atau pembentukan kompetensi dikatakan berhasil dan berkualitas apabila seluruhnya atau setidak-tidaknya sebagian besar (75\%) terlibat secara aktif, baik fisik, mental maupun 
social dalam proses pembelajaran. Sedangkan dari segi hasil, proses pembelajaran dikatakan berhasil apabila terjadi perubahan tingkah prilaku yang positif pada diri peserta didik seluruhnya setidaktidaknya sebagian besar (75\%). Selanjutnya proses pembelajaran dikatan berhasil dan berkualitas apabila masukan merata, menghasilkan output yang banyak dan mutu tinggi, serta sesuai dengan kebutuhan, perkembangan masyarakat dan pembangunan.

R.M. Gagne pada Mohamad Surya mengemukakan, bahwa hasil pembelajaran ialah berupa kecakapan manusiawi (human capabelities) yang meliputi: 1) Informasi verbal 2) Kecakapan intelektual, yang terdiri dari: (a) Diskriminasi, (b) konsep konkrit, (c) konsep abstrak, (d) aturan, dan (e) aturan yang lebih tinggi. 3) Strategi Kognitif 4) Sikap, dan 5) Kecakapan motorik. Pembelajaran belum dikatakan lengkap apabila hanya menghasilkan perubahan satu atau dua aspek saja. (Surya: 2004:17).

\section{PROSEDUR PENELITIAN}

Penelitian mempergunakan metoda deskriptif dengan pendekatan kuantitatif. Variabel penelitian meliputi variable bebas kesatu yaitu system manajemen kepala sekolah sedangkan variable bebas kedua yaitu kinerja guru sedangkan, variable terikat adalah kualitas pembelajaran. Teknik yang digunakan adalah teknik kuesioner, dokumentasi, dan wawancara.

\section{HASIL PENELITIAN}

Hasil penelitian ini adalah sebagai berikut.

Sistem manajemen kepala sekolah meliputi: perencanaan (planning), pengorganisasian (organizing), penggerakkan (actuating), penggkoordinasian (coordinating), pengarahan (directing), dan pengawasan (controlling). Sistem menajemen kepala sekolah menghasilkan angka rata rata 4,04 berada pada interval 3,5- 4,5 termasuk katagori baik artinya system manajemen kepala sekolah SD Laboratorium PPL UPI Kecaman Cileunyi pada umumnya tergolong baik.

Kinerja mengajar guru meliputi kemampuan professional, kemampuan social dan kemampuan pribadi. Perolahan angka rata rata berada pada interval 3,5-4,5 tergolong baik. Artinya kinerja mengajar guru SD Laboratorium PPL UPI Kecamatan Cileunyi secara umum tergolong baik.

Kualitas pembelajaran dinyatakan dengan perolehan nilai rata rata kelas mulai kelas I sampai kelas VI cenderung mengikuti model distribusi normal artinya ada SD yang sudah menunjukkan kualitas pembelajaran termasuk baik, tapi ada pula yang masih kurang baik. Rata rata nilai sekolah yang dijadikan unit analisis adalah 6, 97 pada skala 10. Nilai 6, 97 mendekti 7 sehingga dapat ditafsirkan kualitas pembelajaran pada SD Laboratorium PPL UPI Kecamatan Cileunyi termasuk cukup.

Sistem manajemen kepala sekolah berpengaruh positif signifikan terhadap kinerja gurusebesar 15 , $70 \%$.

Kinerja mengajar guru berpengaruh positif signifikan terhadap kualitas pembelajaran sebesar 25,00 $\%$.

Sistem manajemen kepala sekolah berpengaruh positif signifikan terhadap kualitas pembelajaran sebesar 10,90\%.

Sistem manajemen kepala Sekolah dan kinerja mengajar guru secara simultan berpengaruh positif signifikan terhadap kualitas pembelajaran sebesar $27,00 \%$. 


\section{DAFTAR PUSTAKA}

Aas Syaefuddin. (2003). Administrasi Kepemimpinan dan Supervisi Kepemimpinan STKIP Siliwangi Bandung

Anwar Q. Syaeful Sagala. (2004). Profesi Jabatan Kependididkan Dan Guru Sebagai Upaya Penjamin Kualitas Pembelajaran. Jakarta : UHAMKA PRESS

A. R. Tilaar. (2001). Manajemen Pendidikan Nasional. Bandung : Rosda Remaja Karya.

Berney, Tony, (1998). Strategis for Successful Leadership. Japan Europa Japan Centre

BaPeDa Prop. Jawa Barat. (2002). Rencana Pembangunan Regional Makro Pendidikan Jawa Barat. Bandung

Casson, Herbet.H. (1996). Bagaiman Seharusnya Jadi Pemimpin. Bandung: Alma Arip.

Kartono K. (2003). Pemimpin Dan Kepemimpinan. Jakarta: Raja Grafindo Persada.

Nanang Fattah. (2003). Konsep Manajemen Berbasis Sekolah (MBS) Dan Dewan Sekolah. Bandung: Remaja Rosda Karya.

Siagian, S. (1999). Teori Dan Praktek Kepemimpinan. Jakarta : PT Rineka Cipta.

Simamora. H. Manajemen Sumber Daya Manusia. Yogyakarta: STIE YKPN

Sugiyono. Metode Penelitian Administrasi. Bandung: Penerbit: Alfabeta.

Team Dosen Jurusan Administrasi Pendidikan. (2003). Pengantar Pengelolaan Pendidikan. Universitas Pendidikan Indonesia.

Udin Syaefuddin Saud.(2003). "Masalah Kontenporer Pengelolaan Pedidikan Nasinal”, dalam Pengantar Pengelolaan Pendidikan. Universitas Pendidikan Indonesia.

Undang-Undang Republik Indonesia No.20 Tahun 2003 Tentang Sistem Pendidikan Nasional. Jakarta : BPResindo Mediatama.

Winardi.(2000). Kepemimpinan Dalam Manajemen. Jakarta: PT Rineka Cipta

\section{BIODATA PENULIS}

Ening Widaningsih adalah Dosen Program Studi S1 PGSD UPI Kampus Cibiru 